\title{
ABOUNDANCE CHEESE: EFFECT OF MILK OF HYBRID DAIRY COW'S ( BALADI)) ON THE QUALITY AND PROPERTIES OF THE RESULTANT CHEESES
}

Ahmed, M. A.

Dairy Technology Department, Animal Production Research Institute, Agriculture Research Center, Dokki, Giza, Egypt

\section{ABSTRACT}

Dairy cows belonging to three different genetic types (pure Baladi (B), and their F2 crossbreds, with French Aboundance ( $\mathrm{A} \times \mathrm{BA}$ ) and Tarentaise breed $(\mathrm{T} \times \mathrm{BT})$, were feeding on diets contained similar proportions of concentrate feed, energy and nitrogen contents. Milks yielded from these different crossbreds dairy cows were used in the manufacture of Aboundance cheeses ( a semi-hard cheese) .Cheeses were analysed phsico-chemically, bacteriology and organoleptically when fresh ,and after 30,60 and 90 days of ripening .

Results indicated that, the milk fat in Baladi cows breed (B) was relatively lower than the other two groups $\mathrm{T}$ X B T and A X BA, while milk protein, lactose, ash, total solids, solids not fat and titratable acidity were slightly higher in crossbred cow's milk. Milk of A×BA breed had slightly best chemico-physical properties than the other two groups .

Aboundance cheese manufactured from A X AB milk had slightly higher values of dry matter (DM), Fat/DM, Protein / DM, Salt / Moisture and Titratable acidity and lower values of moisture /non-fat solids and $\mathrm{pH}$ compared with T X B T and B cheeses either when fresh or within ripening period. Most of these parameters were increased in all cheeses during ripening. Concerning the values of cheese ripening indices and total volatile fatty acids, it was found that $\mathrm{A} \times \mathrm{BA}$ cheeses recorded the highest values, along the ripening period .

Sensory evaluation revealed that cheeses of Aboundance were slightly preferred organoleptically, all over the ripening period, than the Tarentaise or Baladi cheeses. It characterized by clean flavor, firm and good body and texture.

\section{INTRODUCTION}

Aboundance cheese is a semi-hard cheese with a subtle hazelnut flavor that is often enjoyed as is or melted. It has enjoyed Protected Designation of Origin (PDO) status since 1990, meaning that it can only be made in a certain geographical area using time-tested traditional 
methods of production. It gets its name from one of the primary breeds of cattle that are used to make it, and also the Abondance Valley where it's made in the Haute Savoie department of southeastern central France, in the Alps. The valley is located in a mountainous area of the department on the border of Switzerland. Only three breeds of cattle are authorized for making Abondance cheese ; Abondance (of course), Tarentaise and Montbéliarde. After 2020, at least 55\% of each herd is used for the production of the cheese, ( Bugaud, et al., 2001) .

Abondance cheese has a strong smell, an intensely fruity, buttery and hazelnut flavour, with the balance of acidity and sweetness, followed by a lingering aftertaste. Unearth an aroma of nutty vegetation as you slice the cheese. Firm but supple and slightly grainy, the texture of the ivory-yellow pâté is creamy and velvety. Its rind is smooth with an amber colour showing canvas marks. The affinage takes at least 100 days, so all the subtle aroma is realized.

The quality of cheese depends on a number of factors linked both to cheese-making technology and to the chemical and microbiological characteristics of the raw materials used. These characteristics are themselves dependent on upstream factors (genetic, physiological or dietary). The ultimate goals of cheese making are not only high predication efficiency and maximum yield but also quality characteristics such as flavor and texture. The major factor in the cheese quality is the starter culture. The ability of starter culture to grow and produce sufficient lactic acid and enzymes depends on some environmental factors such as chemical composition and $\mathrm{pH}$ of milk. Titratable acidity plays an important role in all phases of milk coagulation (Ali, 2006). Curd firmness of milk plays an important role in determining the suitability of milk for some purposes. The low curd firmness milk is not recommended for cheese making (Ali, 2006). In cheese making process, the properties of the curd affect greatly on the characteristics of the produced cheese. Syneresis of curd formed by rennet is an essential step in cheese making which control the moisture content (Marshal, 1982). On the contrary, few reports have been published concerning the crossbreeding of the cows Baladi cattle with Aboundance and Tarentaise breeds. The upgrading of the Baladi cattle with the European breeds was aimed to increasing milk and meat production in the country (Afifi et al., 2001). The two breeds, Abondance and Tarentaise are distinctive in their ability to stand extreme variations in temperature and forages .

Some authors found inter-breed differences in milk fat (MF) composition, resulting in different technological properties with the potential to produce unique milk products (Auldist et al., 2004; De Marchi et al., 2007). 
Two breeds, Holstein (Friesian) and Jersey, have been tested most frequently (Croissant et al., 2007). Nevertheless, inter-breed differences in MF composition were reported in other breeds, such as Belgian Blue, Brown Swiss, Montbéliarde, Salers and Simmental (Barlowska et al., 2009), particularly in comparison with the Holstein. Numerous studies compared MF composition of indigenous and universally used breeds, including their crossbreds (Palladino et al., 2010).

According to the above-mentioned considerations, the present work was carried out to evaluate the variations in milk constituents, characteristics, quality and properties of Aboundance cheese resulting from multiparous Baladi Cows (B) and their crossbreds with Abondance $\left(\mathrm{A} \times \mathrm{BF}_{2}\right)$ and Tarentaise $\left(\mathrm{T} \times \mathrm{B} \mathrm{F}_{2}\right)$, during ripening

\section{MATERIALS AND METHODS}

\section{Materials}

- Milk: Fresh cow milks of Abondance, Tarentaise and Baladi cows were obtained from the herd of Sides Experimental Station, Animal Production Research Institute, Agriculture Research Center, Egypt .

- Starter: Consisted of (Streptococcus thermophilus, Ldl: Lactobacillus delbrueckii subsp. Lactis) was obtained from Cairo Microbiological Resource Center (MIRCEN), Faculty of Agriculture, Ain Shams, Univ., Egypt .

- Chemicals: All chemicals used in this study were of analytical grade and supplied by BDH, Sigma and Prolabo chemical companies.

- Salt: Commercial salt was obtained from El-Naser Company, Alexandria, Egypt.

- Rennet: Hansen's powder rennet was obtained from CHr. Hansen's Laboratories, Copenhagen, Denmark.

- Ready-made media: Trypton Glucose Extract Agar Medium Code CM127 (TGEA) and Nutrient Agar Medium, were bought from Oxoid Division of Oxoid LTD., London.

\section{Methods}

\section{1. manufacturing of cheese:}

Cheeses were made from raw milk as the method described by (Bugauda et al., 2001).

\subsection{Analytical methods:}

pH values was measured using digital pH-meter (M 41150, USA) equipped with glass electrodes.

Titratabel acidity, moisture, fat and total nitrogen contents were determined according to Ling (1963).

Salt was determined according to Simov (1980). 
Proteolysis water soluble nitrogen (WSN) according to Kuchroo \& Fox (1982), Non protein nitrogen (IDF,1993) and Phousphotungstic acid (5\%) soluble nitrogen (Jarrett et al. , 1982) and measured using the methods described in Ardö and Polychroniadou (1999).

Total volatile free fatty acids : (Kosikowski ,1982) and expressed as $\mathrm{ml}$ of $0.1 \mathrm{~N} \mathrm{NaOH} / 10 \mathrm{~g}$ cheese .

Total bacterial count was determined by the plate count method according to American Public Health Association Method (APHA, 2004).

Rennet coagulation time: was determined using $0.1 \mathrm{ml}$ of $1 \%(\mathrm{w} / \mathrm{v})$ powder rennet in distilled water per $10 \mathrm{ml}$ of milk in a thermostatically controlled water-bath, at $37^{\circ} \mathrm{C}$ and the time taken to the first sings of coagulation was measured for all the samples.

Curd tension (firmness): Shalabi (1987).

Synersis (whey separation): ...... Marshall (1982).

Organoleptic properties: Cheese samples were scored according to (Pappas, et al., 1996) by a panel test of the staff members of both Sidis Experimental Station and Dairy Technology Department, Animal Production Research Institute. The scoring was based on the following scale: Flavour: 50 points, Body \& texture: 35 points, appearance: 5 and color 10 points (Total scores 100 points).

\section{RESULTS AND DISCUSSION}

\section{A - Effect of cow breeds on physico-chemical properties of raw milks:}

1- Physical properties :

1.1 - Rennet coagulation time (RCT): Results indicated that the cow breed has slightly effect on the RCT and a low value was observed in $\mathrm{A} \times \mathrm{BF}_{2}$ milk than the other 2 breeds Table (1). The average values were 9.23, 9.72, and 10.34, min for $\mathrm{A} \times \mathrm{BF}_{2}, \mathrm{~T} \times \mathrm{BF}_{2}$, and $\mathrm{B}$ breed, respectively . These results are agreed with those reported by Davoli et al., (1990). DeMarchi et al. (2007), also, said that in the 5 cattle breeds; Holstein-Friesian (HF), Brown Swiss (BS), Simmental (S), Rendena (R) and Alpine Gray (AG), a better RCT was noticed in R breed than in the other breeds. They added that no differences for RCT values (16.1, 16.2 and 16.0, min.) were recorded among BS, S and AG respectively. The HF breed had the worst milk coagulation values $(18.0, \mathrm{~min})$.

1.2 -Curd tension (CT): CT of milk plays an important role in determining the suitability of milk for cheese-making, so the low CT is not recommended. It was observed that the $\mathbf{C T}$ was increased in milk of $\mathrm{A} \times \mathrm{BF}_{2}$ breed than the other two breeds. The averages values 
were 48.27, 46.19 and 44.32, gm. for $\mathrm{A} \times \mathrm{BF}_{2}, \mathrm{~T} \times \mathrm{BF}_{2}$, and $\mathrm{B}$ breed, respectively. These results are in agreement with those reported by DeMarchi et al., (2007) who stated that the type of milk used for cheese production can be critical when it comes from protected geographic indication, e.g., European label protected denomination of origin. At the current time, very little information's has been published regarding the influence of cow breed on the properties and quality of different cheeses. Many reports indicate small differences in color, fat, composition, and rate of milk coagulation.

1.3 -Curd Syneresis (CS): In cheese making, syneresis of the curd is an essential step in cheese making controlling the moisture content (Marshal 1982).

It was seen that the rate of whey separation $(\mathrm{ml} / 100 \mathrm{ml}$ milk) was slightly low among all cow breeds, Table (1). The average values were 75.3, 77.4, and $79.2 \mathrm{ml} / 100 \mathrm{ml}$ milk for $\mathrm{A} \times \mathrm{BF}_{2}, \mathrm{~T} \times \mathrm{BF}_{2}$, and $\mathrm{B}$ breed, respectively. Titratable acidity plays important role in that and depends on individual and herd animals, reactivity between rennet and casein, aggregation rate of paracasein micelles, and syneresis ability of the curd (Summer et al., 2002). Grandisan et al. (1984) added that titratable acidity represents an important parameter for the technical evaluation of the quality of milk. In addition, they studied the effect of 4 Friesian cows during the first 9 weeks of lactation on the coagulation properties of milk. They noticed that considerable variations were occurred in the relative proportions of $\alpha, \beta$ and $k$-casein. These variations were associated with decreasing the coagulum strength and increasing of whey separation, while rennet clotting time (RCT) did not follow the former significant trend.

1.4-Titratable acidity: Low acid levels in milk manifested considerably longer RCT. In fact, 30 min after rennet addition, such milk supplied a curd with very low firmness if compared with that of milk with normal titratable acidity. Table (1) showed that there were no obvious differences were noticed among the three cow breeds. So the average values were $0.172,0.173$ and $0.175 \%$ for $\mathrm{B}, \mathrm{T} \times \mathrm{BF} 2$ and $\mathrm{A} \times \mathrm{BF} 2$, in order .These results were similar to those reported in Holstein-Friesian breed by (Formaggioni et al., 2001).

2 - Chemical composition of milk:

* Results presented in Table (1) showed that, the milk fat in Baladi cows (B) was relatively lower compared with the other two breeds $\mathrm{T} \times$ $\mathrm{BF}_{2}$ and $\mathrm{A} \times \mathrm{BF}_{2}$. These obtained results are in agreement with 
Bassiouni (2010) who found that, the fat percentage was insignificantly decreased in Baladi cow's milk compared to Tarentaise and Abondance breeds. These values were 3.70, 3.73 and 3.85, respectively (Table 1).

$*$ The $\mathrm{A} \times \mathrm{BF}_{2}$ breed had the highest percentage of total solids, protein, fat and ash than the other 2 breeds. The mean values of total solids in $\mathrm{B}, \mathrm{T} \times \mathrm{BF}_{2}$ and $\mathrm{A} \times \mathrm{BF}_{2}$ were 12.50, 12.67 and 12.91, respectively, while the percentage values of protein were $3.29,3.38$ and 3.51 and ash were $0.77,0.78$ and $0.80 \%$ respectively. These differences in chemical composition among the 3 groups might be related to the differences recorded in its milk constituents.

Table (1): Effect of cow breeds on the phycico-chemical properties of raw milk of Baladi $(B)$ and their $F_{2}$ crossbreds $\left(A \times B_{2}\right.$ and $\mathrm{T} \times \mathrm{BF}_{2}$ ).

\begin{tabular}{|c|c|c|c|}
\hline \multirow{2}{*}{$\begin{array}{l}\text { Chemical composition of } \\
\text { cow's milk }\end{array}$} & \multicolumn{3}{|c|}{ Cow breeds } \\
\hline & B & $\mathbf{T} \times \mathbf{B F}_{2}$ & $\mathbf{A} \times \mathbf{B F}_{2}$ \\
\hline Fat $(\%)$ & 3.73 & 3.77 & 3.85 \\
\hline Protein (\%) & 3.29 & 3.38 & 3.51 \\
\hline Lactose (\%) & 4.71 & 4.74 & 4.75 \\
\hline Ash (\%) & 0.77 & 0.78 & 0.80 \\
\hline Total solids (\%) & 12.50 & 12.67 & 12.91 \\
\hline SNF (\%) & 8.54 & 8.81 & 9.01 \\
\hline pH & 6.6 & 6.5 & 6.4 \\
\hline Titratable acidity & 0.172 & 0.173 & 0.175 \\
\hline $\begin{array}{l}\text { Rennet coagulation time } \\
\text { (min.) }\end{array}$ & 10.34 & 9.72 & 9.23 \\
\hline $\begin{array}{c}\text { Curd tension } \\
\text { (g) }\end{array}$ & 44.32 & 46.19 & 48.27 \\
\hline $\begin{array}{c}\text { Syneresis } \\
\text { ( } \mathrm{ml} / 100 \mathrm{ml} \text { milk) }\end{array}$ & 79.2 & 77.4 & 75.3 \\
\hline
\end{tabular}

Effect of cow breeds on activity and growth of starter bacteria in milk:

* Table (2) there was no clear differences among breeds for $\mathrm{pH}$ value and titratable acidity (TA) during four hours of incubation period, but there were slight differences in its total bacterial counts.

*. The ability of starter culture to grow and produce sufficient amounts of lactic acid and enzymes depends on several factors such as chemical composition and $\mathrm{pH}$ value of milk, activity of starter, type of incubation media, presence of antimicrobial substances, incubation temperature and type of microorganisms in the starter.

* The average values of acidity in $\mathrm{A} \times \mathrm{BF}_{2}$ breed were $0.176,0.44,0.60$, 0.72 and $0.81 \%$ after zero, $1,2,3,4 \mathrm{~h}$. of incubation time. The corresponding values of the acidity for $\mathrm{T} \times \mathrm{BF}_{2}$ breed, were $0.173,0.43$, $0.59,0.68$ and 0.78 , and $0.170,0.38,0.57,0.64$ and 0.73 for the $\mathrm{B}$ breed. $\mathrm{pH}$ values of all breeds behaved reverse trend to titratable acidity . 
* Concerning the total bacterial count (TC) results indicated that the TC in A $\times \mathrm{BF}_{2}$ breed was higher than $\mathrm{T} \times \mathrm{BF}_{2}$ and $\mathrm{B}$ breeds. It was $21.30 \times 10^{5} / \mathrm{g}$ cheese after $4 \mathrm{~h}$. of incubation period. The corresponding ones of $\mathrm{T} \times \mathrm{BF}_{2}$ and $\mathrm{B}$ breeds were 20.80 and $19.60 \times 10^{5} / \mathrm{g}$ cheese. These variations were probably due to the genetic - types of the cows breed.

Table (2): Effect of cow breeds on activity and growth of starter bacteria in milk (pH value, titratable acidity (T.A) and total bacterial counts, T.C $\left(\mathrm{cfu} \times \mathbf{1 0}^{5}\right)$

\begin{tabular}{|c|c|c|c|c|c|c|}
\hline \multirow{2}{*}{ Cow breeds } & \multirow{2}{*}{ Property } & \multicolumn{5}{|c|}{ Incubation time (hr) } \\
\cline { 3 - 7 } & & zero & 1 & 2 & 3 & 4 \\
\hline \multirow{3}{*}{ B } & pH & 6.65 & 6.37 & 6.04 & 5.30 & 4.46 \\
& T.A & 0.170 & 0.38 & 0.57 & 0.64 & 0.73 \\
& T.C & 8.3 & 9.4 & 17.5 & 18.2 & 19.6 \\
\hline \multirow{3}{*}{ T $\times$ BF $_{2}$} & pH & 6.60 & 6.35 & 6.00 & 5.24 & 4.40 \\
& T.A & 0.173 & 0.43 & 0.59 & 0.68 & 0.78 \\
& T.C & 8.3 & 9.6 & 17.9 & 18.8 & 20.8 \\
\hline \multirow{3}{*}{$A \times$ BF $_{2}$} & pH & 6.60 & 6.32 & 5.95 & 5.21 & 4.37 \\
& T.A & 0.176 & 0.44 & 0.60 & 0.72 & 0.81 \\
& T.C & 8.3 & 9.8 & 18.7 & 19.7 & 21.3 \\
\hline
\end{tabular}

\section{B - Physico-chemical composition of Aboundance cheese}

Results present in Table (3) illustrated the physico-chemical composition of Aboundance cheese, during ripening.

Dry Matter (DM, \%):

DM or total solids was found the lowest in B cheese (B) than in the other 2 treatments $(\mathrm{T} \times \mathrm{TB}$ and $\mathrm{A} \times \mathrm{AB}$ cheeses $)$, respectively. $\mathrm{DM} \%$ contents in B fresh cheese was $61.79 \%$ increased to $62.08 \%$, after 90 days of ripening period, while the similar ones of $\mathrm{T} \times \mathrm{TB}$ and $\mathrm{A} \times \mathrm{AB}$ cheeses were 62.86 and $63.68 \%$ in fresh cheeses increased to 63.14 and $64.17 \%$, respectively. Differences of TS among the milk of the 3 breeds may be responsible for that.

Fat on Dry Matter (F/DM, \%):

The Fat / DM of Aboundance cheese was slightly higher in $\mathrm{A} \times \mathrm{AB}$ fresh cheese (52.1\%) than the other ones B and T which were 51.7 and 50.2 $\%$, respectively. Fat / DM contents were decreased in all treatments during ripening period as a result of the action of the lipolytic bacteria as well as the decreasing of moisture. These finding were similar to that reported by Belewu (2006). The variations in fat contents may be attributed, also, to the different genetics and physiological status of the cow breeds (Frank, 1988). Protein on Dry Matter, salt on moisture and moisture on non-fat dry matter:

$\mathrm{A} \times \mathrm{AB}$ cheese had slightly higher values of protein / DM, salt / moisture and Moisture / Non-fat dry matter than in $\mathrm{T} \times \mathrm{TB}$ and $\mathrm{B}$ cheeses , respectively, (Table ,3). These results are in agreement with Myburgh et al. (2012) and Adesina (2012) whom reported that no significant differences were observed in the protein contents in the cow milk 
of the following three breeds: White Fulani, Red Bororo and Muturu. However, several authors were reported a significant effect of type of breed on the milk protein content (Back and Lopez Villalobos, 2007).

Titratable Acidity (TA, \%) and pH value :

TA was found low in B cheeses than in the other 2 cheeses of $(\mathrm{T} \times \mathrm{TB}$ and $\mathrm{A} \times \mathrm{AB}$ cheeses), respectively, along the ripening period. TA after 90 days of ripening was $1.23,1.17$ and $1.12 \%$ for $\mathrm{A}, \mathrm{T}$ and $\mathrm{B}$ cheeses, in a deciding order.

pH values of all cheeses behaved reverse trend to TA, during the ripening period. $\mathrm{pH}$ was found slightly higher in the fresh Baladi cheeses (B) and during 90 days of storage period than those of Tarentaise and Abondance cows' cheeses, respectively.

Table (3) Effect of cow breeds on the physico-chemical composition of Aboundance cheese made from milk of Baladi (B) and their $F_{2}$ crossbreds Aboundance $(A \times B)$ and Tarentaise $(T \times B)$ cows , during ripening.

\begin{tabular}{|c|c|c|c|c|}
\hline \multirow{2}{*}{ parameters } & \multirow{2}{*}{$\begin{array}{l}\text { Ripening period } \\
\text { ( days ) }\end{array}$} & \multicolumn{3}{|c|}{ Cow Breeds } \\
\hline & & B & T X BF2 & A X BF2 \\
\hline \multirow{4}{*}{$\begin{array}{l}\text { Fat / DM } \\
\left(\mathrm{g.100} \mathrm{g}^{-1}\right)\end{array}$} & Fresh & 50.2 & 51.7 & 52.1 \\
\hline & 30 & 49.8 & 50.7 & 51.3 \\
\hline & 60 & 48.9 & 49.8 & 50.6 \\
\hline & 90 & 48.6 & 49.2 & 49.8 \\
\hline \multirow{4}{*}{$\begin{array}{l}\text { Protein / DM } \\
\quad\left(\mathrm{g} .100 \mathrm{~g}^{-1}\right)\end{array}$} & Fresh & 47.89 & 48.34 & 48.97 \\
\hline & 30 & 46.67 & 47.16 & 47.68 \\
\hline & 60 & 46.23 & 46.87 & 47.11 \\
\hline & 90 & 45.26 & 46.12 & 46.77 \\
\hline \multirow{4}{*}{$\begin{array}{l}\text { Salt / Moisture } \\
\left(\mathrm{g} .100 \mathrm{~g}^{-1}\right)\end{array}$} & Fresh & 4.93 & 5.10 & 5.42 \\
\hline & 30 & 5.11 & 5.23 & 5.65 \\
\hline & 60 & 5.24 & 5.44 & 5.78 \\
\hline & 90 & 5.36 & 5.76 & 6.02 \\
\hline \multirow{4}{*}{$\underset{\left(\mathrm{g} .100 \mathrm{~g}^{-1}\right)}{\mathrm{M} / \mathrm{NFD}}$} & Fresh & 53.9 & 53.2 & 52.6 \\
\hline & 30 & 54.2 & 53.6 & 52.8 \\
\hline & 60 & 54.5 & 53.9 & 53.4 \\
\hline & 90 & 54.7 & 54.2 & 53.8 \\
\hline \multirow{4}{*}{ DM \% } & Fresh & 61.79 & 62.86 & 63.68 \\
\hline & 30 & 61.84 & 62.91 & 63.87 \\
\hline & 60 & 61.92 & 62.99 & 63.94 \\
\hline & 90 & 62.08 & 63.14 & 64.17 \\
\hline \multirow{4}{*}{ pH value } & Fresh & 5.86 & 5.78 & 5.72 \\
\hline & 30 & 5.67 & 5.64 & 5.59 \\
\hline & 60 & 5.52 & 5.51 & 5.48 \\
\hline & 90 & 5.49 & 5.46 & 5.43 \\
\hline \multirow{4}{*}{ Titratable acidity $\%$} & Fresh & 0.75 & 0.77 & 0.78 \\
\hline & 30 & 0.85 & 0.89 & 0.91 \\
\hline & 60 & 0.94 & 1.09 & 1.15 \\
\hline & 90 & 1.12 & 1.17 & 1.23 \\
\hline
\end{tabular}

M/NFD: moisture on non-fat dry matter . NaCl /M: salt in moisture. F/DM: fat on dry matter. DM: dry matter.

B: Baladi Cows; $\mathbf{T} \times$ BT: F2 crossbreds with French Tarentaise ; A $\times$ BA: F2 crossbreds with French Aboundance

Proteolysis and lipolysis:

Proteolytic (cheese ripening indices) activity in cheese can be estimated by the release of a small nitrogen-containing fractions (water 
soluble nitrogen/total nitrogen (WSN/TN), the $\mathrm{pH}$ 4.4-SN/TN and phosphotungstic acid-soluble nitrogen/total nitrogen (PTA - SN/TN) (Visser, 1977).

Values of WSN /TN , 4.4-SN/TN and PTA-SN/TN were found higher in $\mathrm{A} \times \mathrm{BA}$ cheeses than in $\mathrm{T} \times \mathrm{BT}$ and $\mathrm{B}$ cheeses ( Table 4). Values of WSN / TN were 6.16, 6.34 and $6.72 \%$ in fresh cheeses of $\mathrm{B}, \mathrm{T} \times \mathrm{BT}$ and $\mathrm{A} \times \mathrm{BA}$ cheeses, respectively. At the end of the ripening period these values were increased gradually to $27.87,27.91$ and $28.18 \%$ for the same cheeses. Microorganisms of starter as well as rennet enzymes and the chemical composition of the milk playing an important role in that.

\section{Lipolysis:}

- Total volatile fatty acids: have strong sensory properties and are important compounds in the flavor and aroma of many dairy products, especially cheese and fermented dairy products (Collins et al., 2003).

- The values of TVFAs of B, T $\times$ BT and A $\times$ BA, cheeses, shown in Table (4), were approximately near in fresh and ripened cheeses of $B, T$ $\times \mathrm{BT}$ and $\mathrm{A} \times \mathrm{BA}$. These values were increased gradually in all cheeses, during ripening .

- A $\times$ BA cheeses had slightly higher values of TVFFAs compared with the $\mathrm{B}, \mathrm{T} \times \mathrm{BT}$ cheeses, during storage.

- The TVFFAs contents in $\mathrm{B}, \mathrm{T} \times \mathrm{BT}$ and $\mathrm{A} \times \mathrm{BA}$ fresh cheeses were 7.2, 7.6 and 7.9, respectively, increased to $21.7,22.1$ and $22.9 \%$, at the end of the ripening period, respectively.

- These results are in agreement with (Dumont and Adda, 1978). The influence of a cow's breed on the milk fatty acids profile could in part be explained by the differences between breeds in the activity of the mammary enzyme stearoyl coenzyme A desaturase which oxidizes C16:0 to C16:1 and C18:0 to C18:1 and is involved in CLA production (Grosclaude, 1988 ).

Table (4) Effect of cow breeds on the cheese ripening indices and total volatile free fatty acids (TVFFAs) contents of Aboundance cheese made from milk of Baladi (B) and their $F_{2}$ crossbreds with French Aboundance $(\mathrm{A} \times \mathrm{B})$ and Tarentaise $(\mathrm{T} \times \mathrm{B})$ cows, during ripening.

\begin{tabular}{|c|c|c|c|c|c|}
\hline \multirow[b]{2}{*}{ Treatments } & \multirow{2}{*}{$\begin{array}{l}\text { Ripening } \\
\text { period } \\
\text { (days) }\end{array}$} & \multicolumn{4}{|c|}{ Property } \\
\hline & & WSN / TN & $\underset{\left(\mathrm{g}-100 \mathrm{~g}^{-1)}\right.}{\mathrm{pH} \text { 4.4-SN/TN }}$ & $\begin{array}{c}\text { PTA-SN/TN } \\
\left({\left.\mathrm{g}-100 \mathrm{~g}^{-1}\right)}^{\text {PT }}\right.\end{array}$ & TVFFA \\
\hline \multirow{4}{*}{ B } & Fresh & 6.16 & 5.22 & 4.23 & 7.2 \\
\hline & 30 & 18.44 & 9.48 & 7.77 & 12.7 \\
\hline & 60 & 24.23 & 14.62 & 8.98 & 19.5 \\
\hline & 90 & 27.87 & 19.65 & 10.32 & 21.7 \\
\hline \multirow{4}{*}{$\mathbf{T} \times \mathbf{B T}$} & Fresh & 6.34 & 5.36 & 4.61 & 7.6 \\
\hline & 30 & 18.78 & 9.92 & 8.12 & 13.2 \\
\hline & 60 & 24.77 & 15.64 & 9.16 & 20.3 \\
\hline & 90 & 27.91 & 20.11 & 10.72 & 22.1 \\
\hline \multirow{4}{*}{$\mathbf{A} \times \mathbf{B A}$} & Fresh & 6.72 & 6.72 & 4.76 & 7.9 \\
\hline & 30 & 19.84 & $\mathbf{1 0 . 1 3}$ & 8.13 & 13.6 \\
\hline & 60 & 25.86 & 16.00 & 9.27 & 20.6 \\
\hline & 90 & 28.18 & 20.74 & 11.03 & 22.9 \\
\hline
\end{tabular}




\section{Organoleptic properties of Aboundance cheese}

The few studies undertaken on the effect of breed on the sensory characteristics of cheeses were mainly initiated following questions raised by the PDO cheese channels on the relevance of restricting, as part of their specification requirements, milk production to certain breeds only, and in particular to those traditionally breed locally. Early studies in Auvergne did not elicit any significant sensory differences between Saint-Nectaire cheeses made with milk from either Holstein or Montbéliarde cows (Garel and Coulon, 1990). The Tarentaise cattle breed, included in the PDO Beaufort specifications, differs from other dairy breeds in its higher frequency of rare variants of $\alpha \mathrm{s} 2, \beta$ and $\kappa$-caseins. The cheese-making consequences of this particularity have been explored. This study revealed the originality of variant $C$ of $\beta$-casein, whose frequency was as high as $17 \%$ in the Tarentaise breed, whereas it was nearly non-existent in most other dairy breeds in France (Grosclaude, 1988).

Results in Table (5) showed cheeses made with Baladi cows B milk (B , control) were more yellow in color and tended to be slightly bitter. The sensory properties of the other two cheeses $(\mathrm{A} \times \mathrm{BA}$ and $\mathrm{T} \times \mathrm{BT})$ were slightly superior than $\mathrm{B}$ cheese. Cheeses made from Abondance and Tarentaise cow milk were firmer, more melting and tastier than those made with the milk of Baladi cows. Sensory evaluation revealed that cheeses of Aboundance were slightly preferred organoleptically, all over the ripening period, than the Tarentaise or Baladi cheeses. Abondance cheeses were characterized by clean flavor, firm and good body and texture.

Table (5) Organoleptic properties of Aboundance cheese made from cows milk of Baladi (B) and their F2 crossbreds (French Aboundance $(\mathrm{A} \times \mathrm{BA})$ and Tarentaise $(\mathrm{T} \times \mathrm{BT})$, during ripening.

\begin{tabular}{|c|c|c|c|c|c|c|}
\hline \multirow{4}{*}{ Treatments } & $\begin{array}{c}\text { Ripening } \\
\text { period } \\
\text { days })\end{array}$ & $\begin{array}{c}\text { Flavour } \\
(50)\end{array}$ & $\begin{array}{c}\text { Body \& } \\
\text { Texture } \\
(35)\end{array}$ & Appearance (5) & $\begin{array}{c}\text { Color } \\
10\end{array}$ & $\begin{array}{c}\text { Total } \\
(100)\end{array}$ \\
\cline { 2 - 8 } & Fresh & 44.42 & 31.8 & 4.2 & 8.4 & 88.82 \\
\hline \multirow{4}{*}{ B } & 30 & 45.15 & 32.2 & 4.4 & 8.5 & 90.25 \\
\cline { 2 - 8 } & 60 & 46.00 & 32.7 & 4.4 & 8.6 & 91.70 \\
\cline { 2 - 8 } & 90 & 46.53 & 32.8 & 4.5 & 8.6 & 92.43 \\
\cline { 2 - 8 } & Fresh & 44.68 & 32.8 & 4.3 & 8.8 & 90.58 \\
\hline \multirow{4}{*}{ T $\times$ BT } & 30 & 45.77 & 33.5 & 4.4 & 8.9 & 92.57 \\
\cline { 2 - 8 } & 60 & 46.35 & 33.6 & 4.4 & 8.9 & 93.25 \\
\cline { 2 - 8 } & 90 & 46.79 & 33.8 & 4.5 & 8.9 & 93.99 \\
\hline \multirow{4}{*}{ A $\times$ BA } & Fresh & 44.91 & 33.1 & 4.3 & 9.0 & 91.31 \\
\cline { 2 - 8 } & 30 & 45.94 & 33.9 & 4.5 & 9.1 & 93.44 \\
\cline { 2 - 8 } & 60 & 46.62 & 34.2 & 4.5 & 9.1 & 94.42 \\
\cline { 2 - 8 } & 90 & 46.96 & 34.3 & 4.6 & 9.1 & 94.96 \\
\hline
\end{tabular}


Differences in cheese quality can be due to intrinsic animal characteristics and this was apparent in Beaufort type cheeses or traditional Caprine cheeses which depended on the type of milk and / or $\alpha$-s1 casein variants (Marie and Delacroix-Buchet, 1994 and Vassal et al., 1994), while differences in color and flavour depended on breed of Friesian vs Jersey herds (Keen and Wilson, 1993). Martin and Coulon (1995) added that the variations in the sensory qualities are initially controlled by the cheese making technology and especially by the kinetics of acidification during the manufacture.

\section{CONCLUSION}

It is clear that the superiority of crossbred cows especially the second generation of Aboundance or Tarentaise breeds with Baladi $(\mathrm{A} \times \mathrm{BA}$ and $\mathrm{T} \times \mathrm{BT})$ was over than pure Baladi (B ) cow's and it could be recommended from the economical point of view to improve milk quality and its properties and cheese made from that milk. Certain differences in cheese characteristics were depended on the type of animal breed, feeding and the numerous empirical observations (Urbach, 1990).

Our study revealed that the milk of the three breeds (Aboundance ,Tarentaise and Baladi cow ) were of good quality, as a general, and was suitable for manufacturing Aboundance cheese. Milk of Aboundance breed $(\mathrm{A} \times \mathrm{BA})$ was slightly preferred and followed by Tarentaise ( $\mathrm{T} \times$ BT) and Baladi cow, in order.

\section{REFERENCES}

Adesina K.(2012). Effect of Breed on the Composition of Cow Milk under Traditional Management Practices in Ado-Ekiti, Nigeria. J. Appl. Sci. Environ. Manage. 16:55 - 59.

Afifi, E.A. ; MF. Abdel-Glil and S.A. Arafa (2001). Effect of crossing and grading Domiati cattle with two European breeds in Egypt. Annals Agric. Sci. Moshtohor, Egypt. 34(4):1517-1535.

Ali, M.A. (2006): Activity of proteolyticenzymes during the ripening of low-fat Ras cheese. Ph.D. Thesis,Fac.Agric., Minia Univ.

American Public Health Association (APHA) (2004). Standard methods for the examination of diary products. Amer. Publ. Health Assoc. Inc. $12^{\text {th }}$ ed., New York.

Ardö, Y. and A. Polychroniadou (1999). Laboratory manual for chemical analysis of cheese, Office for official publications of the European communities, Luxembourg. 
Auldist, M.J. ; K.A. Johnston ; White N.J. ; W.P. Fitzsimons and M.J. Boland (2004).A comparison of the composition, coagulation characteristics and cheesemaking capacity of milk from Friesian and Jersey dairy cows. J.of Dairy Res., 71(1):51-57.

Back, P.J. and N. Lopez Villalobos (2007). Breed and heterosis effects for milk protein composition estimated in two stages of lactation in New Zealand dairy cows. Proceedings of the New Zealand Society of Animal Production, 67: 399-402.

Barlowska, J. ; T. Grodzicki ; B. Topyla and Z. Litwinczuk (2009). Physicochemical properties of milk fat from three breeds of cows during summer and winter feeding. Arch. Tierz.-Arch. Anim. Breed., 52: 356-363.

Bassiouni, Nagwa A.T. (2010). A comparative study on mammary gland activity in baladi cows and their crossbreds with French abondance and tarentaise cows. Ph.D. Thesis, Fac. Agric., Cairo Univ.

Belewu, M.A. (2006). A Functional approach to Dairy Science and Technology. Adlek Printing Enterprises, Ilorin. pp117 - 136.

Bugauda, C. ; S. Buchina ; Y. Noëla ; L. Tessiera ; S. Pocheta ; Martinb B. and J.F. Chamba (2001) . Relationship between Abondance cheese texture, its composition and that of milk produced by cows grazing different types of pastures. Lait 81:593- 607 .

Collins, Y.F. ; P.L.H. McSweeney and M.G. Wilkinson (2003). Lipolysis and free fatty acid catabolism in cheese: A review of current knowledge. Int. Dairy J., 13:841-866.

Croissant, A.E., Washburn, S.P., Dean, L.L. \& Drake, M.A., 2007. Chemical properties and consumer perception of fluid milk from conventional and pasture-based production systems. J. Dairy Sci., 90: 4942-4953.

Davoli, R. ; S. Dall Olio and V. Russo (1990) .Effect of қ-casein genotype on the coagulation properties of milk. J. Anim. Breed Genet., 107: 458-464 .

De Marchi, M. ; R. Dal Zotto ; M. Cassardro and G. Bittante (2007) . Milk Coagulation Ability Of Five Dairy Cattle Breeds. J. Dairy Sci., 90: 3986-3992 .

Dumont, J.P. and J. Adda (1978). Occurrence of sesquiterpenes in mountain cheeses volatiles, J. Agric. Food Chem., 26: 364-367.

Formaggioni, R. ; M. Malacarne ; A. Summer ; E. Fossa and P. 
Mariani (2001). Milk with abnormal acidity. The role of phosphorus content Journal of Dairy Science, 90 (8): 2007 and the rennet-coagulation properties of Italian Friesian herd milk. Ann. Fac. Med. Vet. Univ. Parma, 21:261-268

Frank, O.(1988) . Rural Dairy Technology Experience in Ethiopia. ILCA Manual., 4:1- 10 .

Garel, J.P. and J.B. Coulon (1990). Effet de l'alimentation et de la race des vaches sur les fabrications de fromage d'Auvergne de SaintNectaire, INRA Prod. Anim., 3:127-136.

Grandisan, S.A. ; D.G. Ford ; David Millard and A. Jane Owen (1984). Chemical composition and coagulation properties of renneted milks from cows during early lactation. J. of Dairy Res., 51 (3):407-416.

Grosclaude, F. (1988). Le polymorphisme génétique des principales lactoprotéines bovines. Relation avec la qualité, la composition et les aptitudes fromagères du lait, INRA Prod. Anim., 1: 5-17.

Jarrette, W.D. ; J.W. Aston and J.R. Dulley (1982). A simple method for estimating free amino acids in Cheddar cheese. Aust. J. of Dairy Tech., 37: 55-58.

Keen, A.R. and Wilson R.D. (1993). Effect of breed on colour and flavour. In: Mi/kfat flavour forum, summary of proceedings. Palmerston North, New Zealand, 50-54

Kosikowski, F. (1982). Cheese and Fermented Milk foods. Second Edition published by F.V. Kosikowski and Associates, New York.

Kuchroo, C.N. and P.F. Fox (1982). Soluble nitrogen in Cheddar cheese. Comparison of extraction procedures. Milchwissenschaft, 37(6): 331-335.

Ling, E.R. (1963). "A text Book of Dairy Chemistry". Vol. II, practical, $3^{\text {rd }}$ edition publishers Chapman and Hall Limited, London.

Macheboeuf, D. ; J.B. Coulon and P. D'Hour (1993). Effect of breed, protein genetic variants and feeding on cows' milk coagulation properties, J. Dairy Res., 60: 43-54.

Marie, C. and A. Delacroix-Buchet (1994). Comparaison des variants A et $\mathrm{C}$ de la caséine $\sim$ des laits de vaches Tarentaises en modèle fromager de type beaufort. II. Protéolyse et qualité des fromages. Lait, 74: $443-459$.

Marshall, R.J. (1982). An improved method for measurment of the syneresis of curd formed rennet action on milk. J. Dairy Res. $49: 329-336$. 
Martin, B. and J.B. Coulon (1995). Milk production and cheese characteristics . 11. Influence of herd milk characteristics and cheesemaking methods on farmhouse French Reblochon Cheeses characteristics (in French). Le Lait, 75: 133-149.

Myburgh, J. ; G. Osthoff ; A. Hugo ; M. de Wit ; K. Nel and D. Fourie. (2012). Comparison of the milk composition of free-ranging indigenous African cattlebreeds. South African Journal of Animal Science., 42:1-14.

Palladino, R.A. ; F. Buckley ; R. Prendiville ; J.J. Murphy ; J. Callan and D.A. Kenny (2010). A comparison between Holstein-Friesian and Jersey dairy cows and their F-1 hybrid on milk fatty acid composition under grazing conditions. J. Dairy Sci., 93: 21762184.

Pappas, C.P. ; E. Kondly ; L.P. Voustsinas and H. Mallatou (1996): Effect of starter level, draining time and aging on the physiochemical, organoleptic and rheological properties of Feta cheese. J. of Society of Dairy Tech., 49: 73.

Shalabi, S.I. (1987). Milk clotting activity of commercial rennet substitutes. A comparative study . Menia J. Agric. Res. Dev., 2:441-460 .

Simov, G.U. (1980).Technological of milk products, Atext Book, Plovidiv. P. 162.

Summer, A. ; M. Malacarne ; F. Martuzzi ; P. Mariani (2002).Structural and fuctional characteristics of Modenese cow milk in ParmigianoReggiano cheese production. Ann. Fac. Med. Vet. Univ. Parma., $22: 163-174$.

Urbach, G. (1990). Effect of feed on flavor in dairy foods. J Dairy Sci 73, 3639-3650

Vassal, L. ; A. Delacroix-Buchet and J. Bouillon (1994) Influence des variants $\mathrm{AA}, \mathrm{EE}$ et $\mathrm{FF}$ de la caséine as1 caprine sur le rendement fromager et les caractéristiques sensorielles de fromages traditionnels premières observations. Lait, 74: 89.

Visser, F.M.W. (1977): Contribution of enzymes from rennet, starter bacteria and milk to proteolysis and flavour development in Gouda cheese. 1. Description of cheese and aseptic cheese making techniques. Neth. Milk Dairy J. 31: 120.

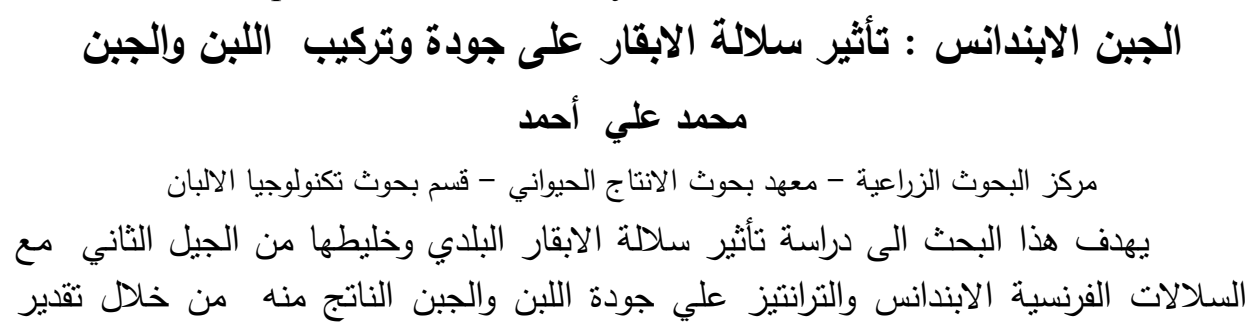


التزكيب الكيماوي والصفات الطبيعيه ونشاط ونمو بكتريا البادئ في اللبن ، وكنلك دراسة

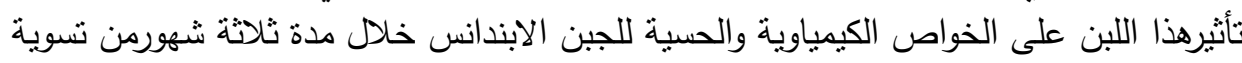

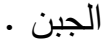

تم تصنيع الجبن الابندانس من اللبن البقري الخام ، دون بسترة ، من ناتج السلالات البات الباتئ

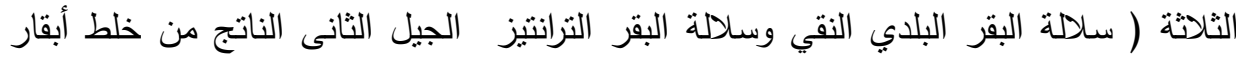
الجيل الاول مع الترانتيز، وسلالة البقر الابندانس الجيل الثانى الناتج من خلط أبقار الجيل البانيل

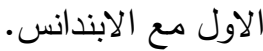

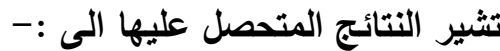
* تلاحظ ارتفاع طفيف للاهن والبروتين واللاكتوز والرماد والمواد الصلبة الكلية والمواد الصلبة اللأدهنية * والحموضة بالنسبة للبن سلالة الابندانس الخليط يليها سلالة البقر الترانتيز وأخيرا سلالة

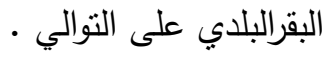
" تلاحظ زيادة نمو ونشاط بكتريا البادئ فى لبن سلالة الابندانس. * ت تلاحظ ان لبن سلالة الابندانس أفضل في صفات التجبن سواء زمن التجبن وقوام الخثرة

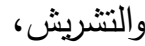
* تلاحظ ارتفاع بسيط في كل من المادة الجافة ، والدهن بالنسبة للمادة الجافة، والبروتين

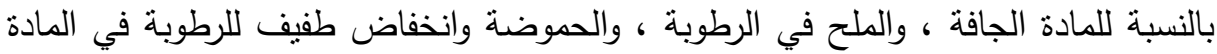

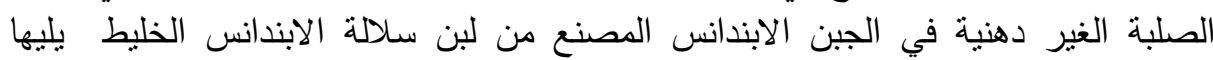

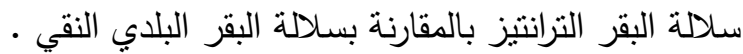

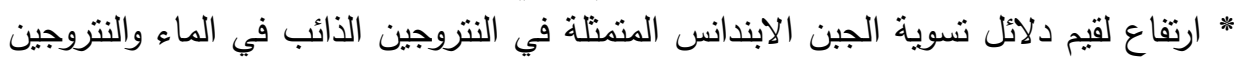

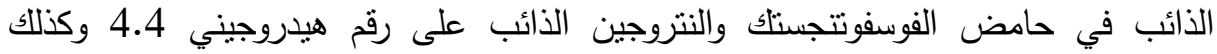

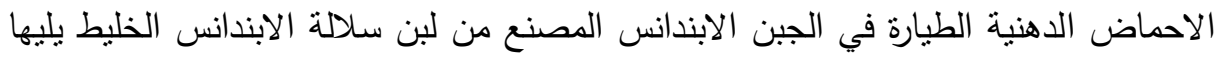

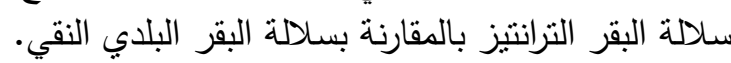

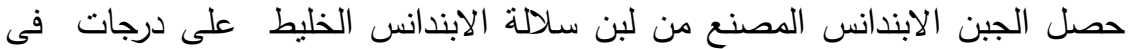

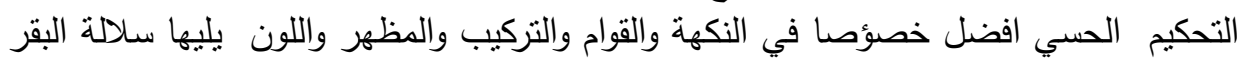

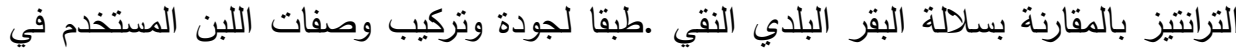

